added to the number of the victims of consumption.

We regret to state that $\mathrm{Mr}$. Dobson was not enabled to leave a provision for an amiable wife and two infant children, who are therefore left destitute by his death. Under these distressing circumstances, several gentlemen, professional friends of the deceased, have entered into a subscription for the widow and children, the particulars of which will, we presume, be duly and extensively advertised.

We take this opportunity of apologizing to some of our correspondents, and to the whole of our readers, in consequence of Beveral typographical errors which appeared in Tre Lancer of last week. Unfortunately it was not discovered until a late hour that we should be called on to publish that number of the Journal on Thursday, as the following day happened to be Good Friday. From this circumstance several of the articles went to press without the proofsheets having been read by the Editor. In the leading article there were two or three ludicrous errata. In one place the writer was represented as having devoted "thirty' years to the cause of medical reform, instead of thirteen, and in the prescriptions of the notorious Bread Pills, there was manifested a singular confusion of terms. We therefore now place them before the non-medical reader in a corrected form, and although Roderick, -- poor RoDerick,may believe that the error was waggishly, or, if he will, maliciously introduced, in order to furnish us with a plausible excuse for bringing his nostrum once more before the public, we veritably assure him that he owes his this week's notoriety to accident, and to that alone. The prescriptions for the Bread Pills of Roderick Macleor, Physician of St. George's Hospital, should have stood in the last LAxceT thus :-

" PILUle eX Mica PILLS From crumb PANis.

" Bo Mice panis zi. Take of Crumb of

Divide in pilulas Bread one drachm. Divide in pilulas Divide into twelve xii, quarum una su- pills, of which let one matur ter quotidie." daily.

\section{MR. WEISS'S LITHOTRITE.}

\section{To the Editor of THE LANCET.}

Sin: I have read in your last number some observations of Mr. Weiss on the sub. ject of his lithotrite, for the confirmation of which he appeals to me. I have always given $\mathrm{Mr}$. Weiss credit for being the inventor of the lithotrite at present in use, as the various instruments now employed are founded upon one constructed by Mr. Weiss long before Baron Heurteloup employed percussion, and I regret that justice has not been done to $\mathrm{Mr}$. Weiss by those who have availed themselves of his invention.

Having, for a long time turned my atten. tion to lithotrity, I have endeavoured to re. medy some of the principal objections to the operation, by an addition to the mechanism of the instrument. With this view I have examined all the lithotrites in use, and have found none so efficient, made with so much exactness, and so safe, as Mr. Weiss's. I have selected, therefore, his instrument for the addition to which allude, and $1 \mathrm{am}$ happy to add that the cases on which I have alread used this instrument, fully bear me out in speaking to its entire efficiency.

Waiving for the present a description of the lithotrite, I beg to remain, Sir, your most obedient servant,

\section{Aston Key.}

St. Helen's-place, April 4th, 1836.

Mr. WARDRop has in the press a work on the Pathology and Treatment of the Diseases of the Heart, to which are prefixed some Physiological Researches on the Circulation of the Blood.

\section{CORRESPONDENTS.}

(From a Correspondent) -The " religion" of King's College, though the stalking-horse of its first days, has been found so unattractive, that it has ceased to be used as a bait, and the compulsion of regular students " to go to chapel" has been wholly given up.

Alpha.-Dr. ** we suppose has not yet had warning enough to get out of the con* cern.

$A$. F.-We reduced the conmunications of "W. C." to statements which did not require personal au hentication. Oherwise that correspondent wonld have been required to attach his name to his letters. The note transmitted by $A$. $F$. wants an address, and would weigh nothing in the scale. The question, lowever, is one not of names, but of facts. 